\title{
Effect of Glyphosate (GLP) Induced Toxicity on Body Weights and Gross Pathology: Ameliorative Effect of Ascorbic Acid (AA) in Wistar Rats
}

\author{
M. Lakshmi Namratha ${ }^{1}$, M. Lakshman ${ }^{1^{*}}$, M. Jeevanalatha ${ }^{2}$ and B. Anil Kumar ${ }^{3}$ \\ ${ }^{1}$ Department of Veterinary Pathology, College of Veterinary Science, \\ Rajendranagar, Hyderabad-500030, India \\ ${ }^{2}$ Department of Veterinary Pathology, College of Veterinary Science, Mamnoor-506166, India \\ ${ }^{3}$ Department of Veterinary Pharmacology and Toxicology, \\ College of Veterinary Science, Rajendranagar, Hyderabad-500030, India \\ *Corresponding author
}

\section{A B S T R A C T}

Keywords

Glyphosate, Albino

Wistar rats, Body

weights Ascorbic

Acid and oral

gavage

Article Info

Accepted:

12 September 2019

Available Online:

10 October 2019
The aim of this study was to determine the body weight changes and gross pathological alterations induced by glyphosate exposure in male albino Wistar rats and its amelioration with Ascorbic Acid. Forty eight (48) adult male albino Wistar rats were used for this study. The experiment was carried out for 21 days. The animals were randomized into 4 groups with twelve (12) animals in each. Group 1 - control, group 2 - GLP (@500 $\mathrm{mg} / \mathrm{kg} \mathrm{b.wt),} \mathrm{group} 3$ - AA (@250 mg/kg b.wt) and group 4 - GLP+AA (@500 mg/kg b.wt + 250mg/kg b.wt). The treatment regimens were administered by oral gavage once daily for three weeks. Individual body weights of all the rats were recorded soon after arrival and subsequently on $7^{\text {th }}, 14^{\text {th }}$ and $21^{\text {st }}$ day of experiment to study the body weight gains. A significant $(\mathrm{P}<0.05)$ reduction in the body weights were recorded in glyphosate treated rats compared to the control rats. On necropsy examination, severe congestion of liver, kidneys and testes and atrophy of kidneys and testicles were recorded in glyphosate treated rats.

\section{Introduction}

Glyphosate (N-phosphonomethyl glycine) is a broad spectrum herbicide widely used to eliminate the unwanted plants both on agricultural and non-agricultural landscapes
(Temple and Smith, 1992). Among all, the glyphosate is a very potential broad spectrum herbicide (Youness et al., 2016) and was first documented in 1971 and is said to be the world's largest selling herbicide. Monsanto brought into the market for agricultural use in 
1974 under the trade name as Roundup ${ }^{\circledR}$. They are used on food crops during cultivation to desiccate the crop before harvest (for instance, wheat) and more intensively used during the cultivation of 80 percent of genetically modified (GM) plants that are engineered to tolerate GBH (James, 2014).

Based upon animal studies, some investigators suggested that the GLP may enhance Adenosine Triphosphatase (ATPase)activity and uncouple mitochondrial oxidative phosphorylation (Bababunmi et al., 1979; Olorunsogo et al., 1979 and Olorunsogo, 1982).Glyphosate toxicity has also been link with inhibition of the growth of beneficial gut bacteria (Shehata et al., 2013). The GLP is a strong chelator of metal cations such as copper, manganese, cobalt, iron and zinc as well as calcium and magnesium (Madsen et al., 1978).

According to Ikpeme et al., (2012) Vitamin C is an essential nutrient involved in the repair of tissues and the enzymatic production of certain neurotransmitters.

Vitamin $\mathrm{C}$ being an antioxidant, is involved in the prevention of cellular damage by safely interacting with free radicals and terminating the chain reactions before vital molecules are damaged. It also removes free radical intermediates and inhibits other oxidative reactions.

Hence, the present experiment was designed to study the toxic effect of GLP and its amelioration with Vitamin $\mathrm{C}$ in male rats.

\section{Materials and Methods}

\section{Experimental animals}

Forty eight (48) adult male albino Wistar rats weighing 200-240 g, bred at Jeeva Life Sciences (ISO 9001:2015 certified company),
Hyderabad were used for this research. The rats were housed in solid bottom polypropylene cages at RUSKA Labs, Department of Veterinary Pathology and were maintained in controlled environment (20$22^{\circ} \mathrm{C}$ ) throughout the course of experiment.

Sterile rice husk was used as standard bedding material. All the rats were provided with standard pellet diet (low fat and nutritionally balanced food) and deionized drinking water ad libitum throughout the experimental period. The experiment was carried out according to the guidelines and prior approval of Institutional Animal Ethics Committee (IAECNo.01-2019).

\section{Chemical source}

Glyphosate was obtained from Seed Research and Technology Centre (SRTC), Professor Jayashankar Telangana State Agriculture University (PJTSAU), Hyderabad-30 under the trade name Roundup ${ }^{\circledR}(41 \%)$ and Vitamin $\mathrm{C}$ was obtained from S.D. Fine-Chem Ltd., Mumbai, India.

\section{Experimental design}

A total of 48 male albino Wistar rats were randomly divided into four (4) groups consisting of twelve (12) animals in each.

Group 1 - Control

Group 2 - GLP (@500 mg/kg b.wt)

Group 3 - AA (@250 mg/kg b.wt)

Group 4 - GLP+AA (@500 mg/kg b.wt + $250 \mathrm{mg} / \mathrm{kg} \mathrm{b.wt)}$

The dose regimens were administered per os once daily for a period of three weeks. The rats were monitored for clinical signs and death. 


\section{Body weights}

Individual body weights of all the rats were recorded using electronic balance on day one soon after arrival and subsequently on $7^{\text {th }}, 14^{\text {th }}$ and $21^{\text {st }}$ day of experiment to study the body weight gains.

\section{Gross pathology}

Six rats from each group were sacrificed on $7^{\text {th }}$ and $21^{\text {st }}$ day of experiment. Experimental rats were sacrificed by gaseous anesthesia (Chloroform) and detailed necropsy examination was carried out as per standard procedure suggested by Feinstein (2000). Gross lesions were recorded in testes, liver and kidneys.

\section{Statistical analysis}

Data obtained were subjected to statistical analysis by applying one way ANOVA using statistical package for social sciences (SPSS) version 16.0. Differences between the means were tested by using Duncan's multiple comparison tests and significance level was set at $\mathrm{P}<0.05$ (Snedecor and Cochran, 1994).

\section{Results and Discussion}

\section{Effect of GLP on clinical signs}

The clinical signs observed in the present study among toxic group rats include anorexia, decreased water intake, dullness, cough, mild diarrhea and weakness (Fig. 1).

\section{Effect of GLP on body weights}

Significantly $(\mathrm{P}<0.05)$ lower mean values were recorded in group $2(256 \pm 1.52,255.83$ \pm 2.73 and $253.17 \pm 3.93)$ and group 4 (264.33 $\pm 2.53,266.67 \pm 1.33$ and $262.67 \pm 2.41$ ) on $7^{\text {th }}, 14^{\text {th }}$ and $21^{\text {st }}$ day of experiment and higher mean values were recorded in group 1 (276.17 $\pm 2.65,277.17 \pm 3.79$ and $283 \pm 2.56)$ and group 3 (277.83 $\pm 2.15,278.67 \pm 4.95$ and $285.33 \pm 6.69)$ on $7^{\text {th }}, 14^{\text {th }}$ and $21^{\text {st }}$ day of experiment. A significant difference was also noticed between the groups 2 and 4 (Table 1 , Fig. 2).

\section{Effect of GLP on gross pathology}

The rats were sacrificed on $7^{\text {th }}$ and $21^{\text {st }}$ day of experiment and gross abnormalities if any were recorded. On necropsy examination, severe congestion of liver, kidneys and testes and atrophy of kidneys and testicles were recorded in group 2 on $7^{\text {th }}$ and $21^{\text {st }}$ day of experiment (Fig. 4 and 8). Mild congestion of liver, kidneys and marked reduction in the size of testicles were recorded in group 4 on $7^{\text {th }}$ and $21^{\text {st }}$ day of experiment (Fig. 6 and 10). The liver, kidneys and testicles revealed normal appearance in groups 1 and 3 on $7^{\text {th }}$ and $21^{\text {st }}$ day of experiment (Fig. 3, 5, 7 and 9).

The clinical signs observed in the present study among toxic group rats include anorexia, decreased water intake, dullness, cough, mild diarrhea and weakness. Similar clinical signs were observed by several authors (Olorunsogo et al., 1979; Stout and Ruecker, 1990; Daruich et al., 2001; Beuret et al., 2005; Cagler and Kolankaya, 2008 and Tizhe et al., 2013).

The decreased water intake may be due to the toxic effect of herbicide or its metabolites on neuroanatomic centers for thirst in the brain (McKenna and Thompson, 1998). The decreased feed and water intake observed in Roundup $^{\circledR}$ treated rats (Group 2) may be attributed to its corrosive action on the GIT. The Vitamin $\mathrm{C}$ pretreated groups did not manifest any toxic signs which signify the amelioration of the toxic effects induced by GLP. However, mortalities were not recorded during the experimental period. 
Table.1 Body weights (g) in different groups

\begin{tabular}{|c|c|c|c|}
\hline GROUP & DAY 7 & DAY 14 & DAY 21 \\
\hline GROUP 1 & $276.17 \pm 2.65^{\mathrm{c}}$ & $277.17 \pm 3.79^{\mathrm{c}}$ & $283 \pm 2.56^{\mathrm{c}}$ \\
\hline GROUP 2 & $256 \pm 1.52^{\mathrm{a}}$ & $255.83 \pm 2.73^{\mathrm{a}}$ & $253.17 \pm 3.93^{\mathrm{a}}$ \\
\hline GROUP 3 & $277.83 \pm 2.15^{\mathrm{c}}$ & $278.67 \pm 4.95^{\mathrm{c}}$ & $285.33 \pm 6.69^{\mathrm{c}}$ \\
\hline GROUP 4 & $264.33 \pm 2.53^{\mathrm{b}}$ & $266.67 \pm 1.33^{\mathrm{b}}$ & $262.67 \pm 2.41^{\mathrm{b}}$ \\
\hline P value & $*$ & $*$ & $*$ \\
\hline
\end{tabular}

Values are Mean \pm SE $(n=6)$; One way ANOVA

Means with different superscripts in a column differ significantly at $\mathrm{P}<0.05$ (*) $^{*}$

Fig.1 Glyphosate treated rat showing mild diarrhea

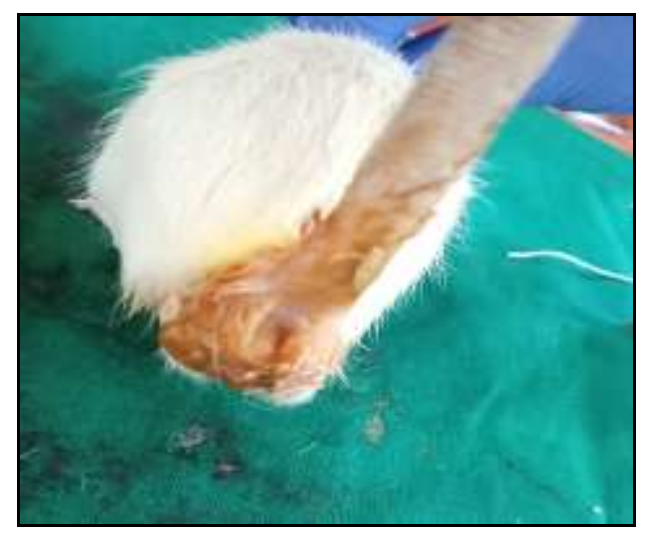

Fig.2 Body weights (g) in different groups

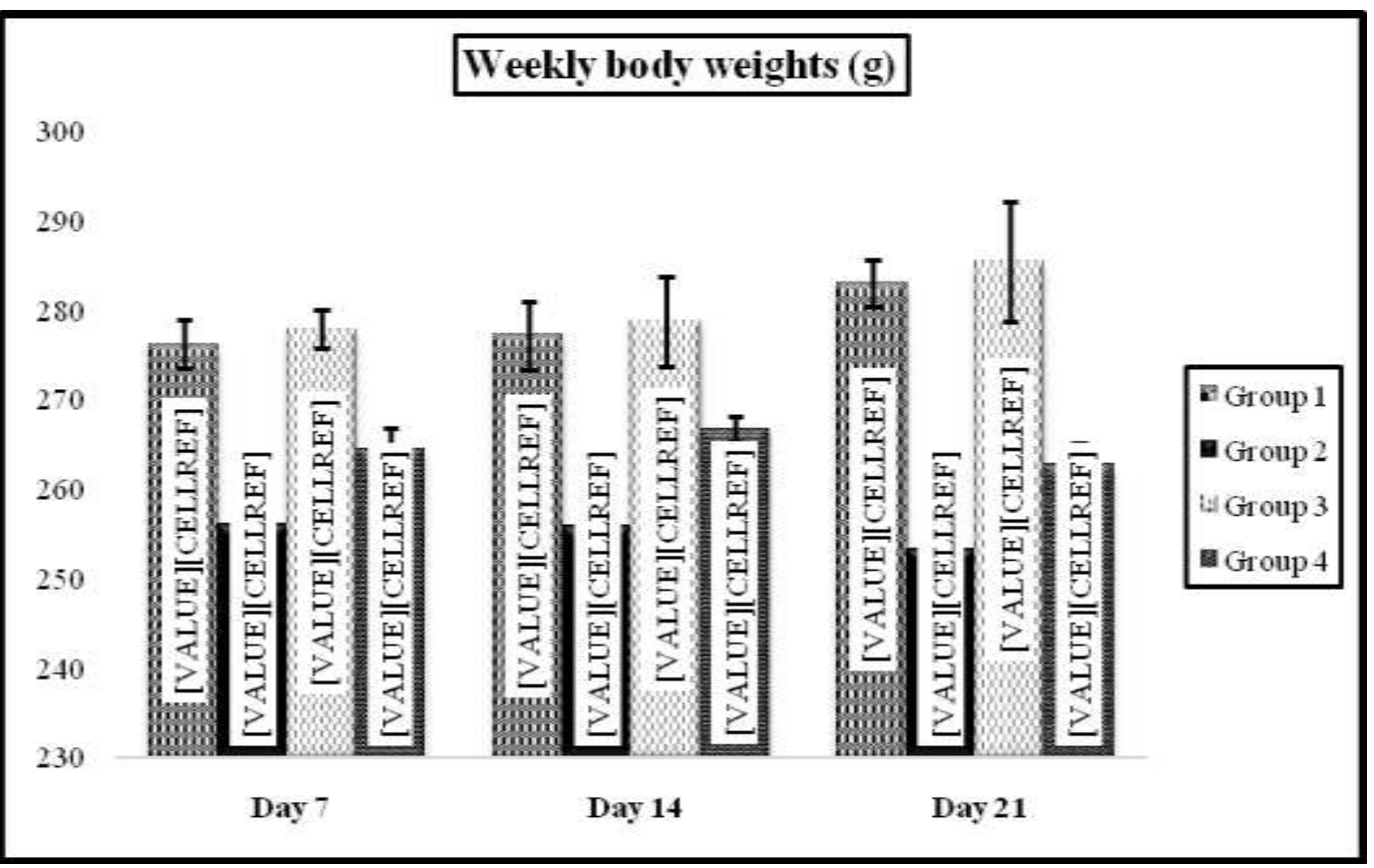


Fig.3 Control rat showing normal appearance of liver, kidneys and testes (Group 1, Day 7)

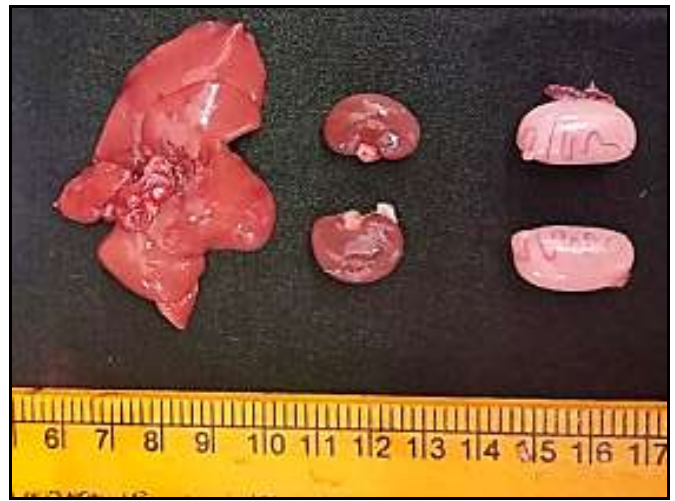

Fig.5 Vitamin $\mathrm{C}$ treated rat showing normal appearance of liver, kidneys and testes (Group 3, Day 7)

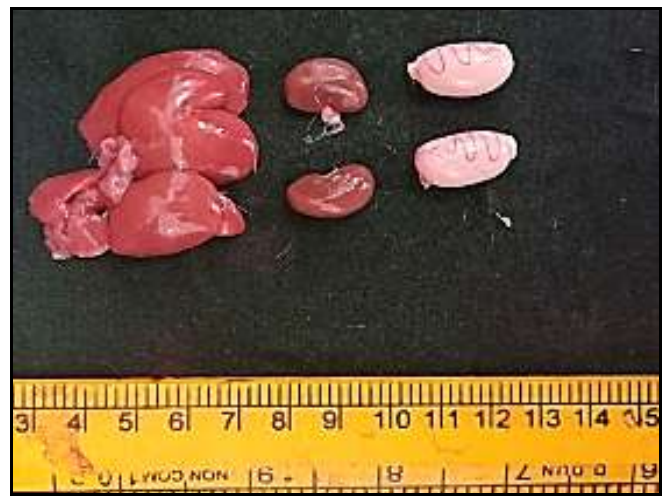

Fig.4 GLP treated rat showing severe congestion of liver, kidneys, decrease in the size of kidneys and marked reduction in the size of testicles (Group 2, Day 7)

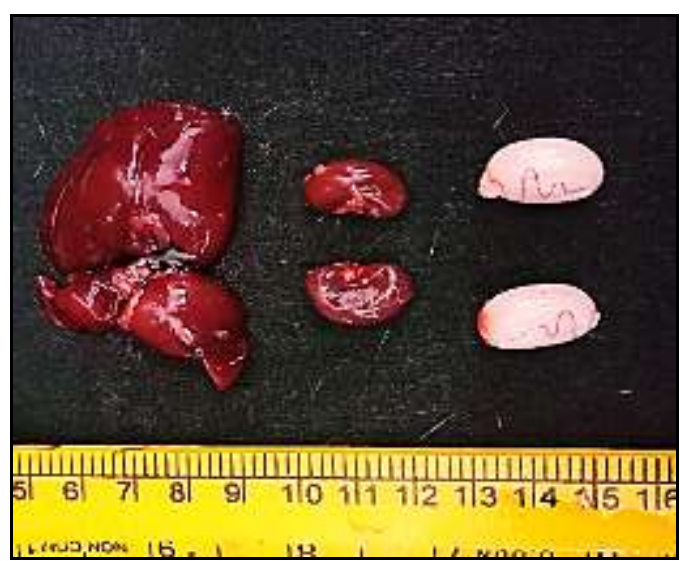

Fig.6 GLP+Vit. $C$ treated rat showing mild congestion of liver, kidneys and moderate reduction in the size of testicles (Group 4, Day 7)

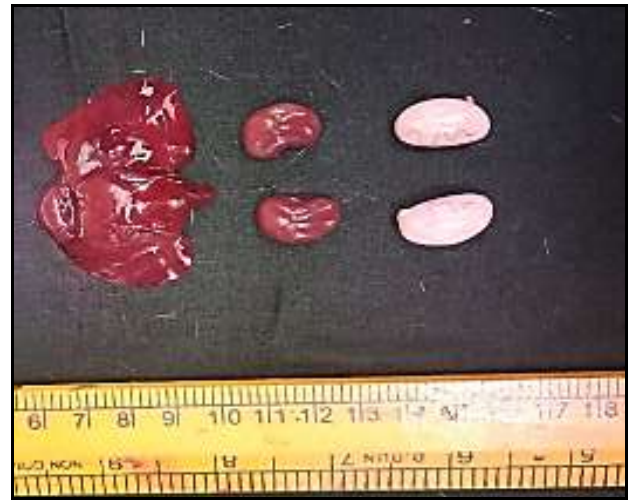

Fig.7 Control rat showing normal appearance of liver, kidneys and testes (Group 1, Day 21)

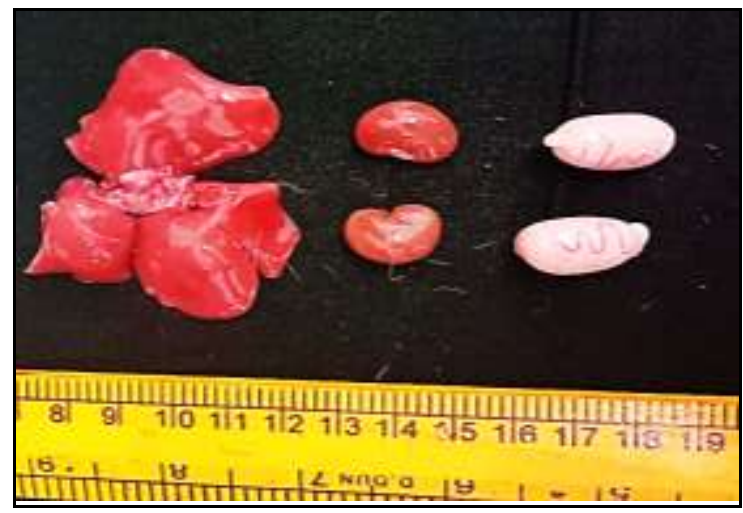

Fig.9 Vitamin $\mathrm{C}$ treated rat showing normal appearance of liver, kidneys and testes (Group 3, Day 21)

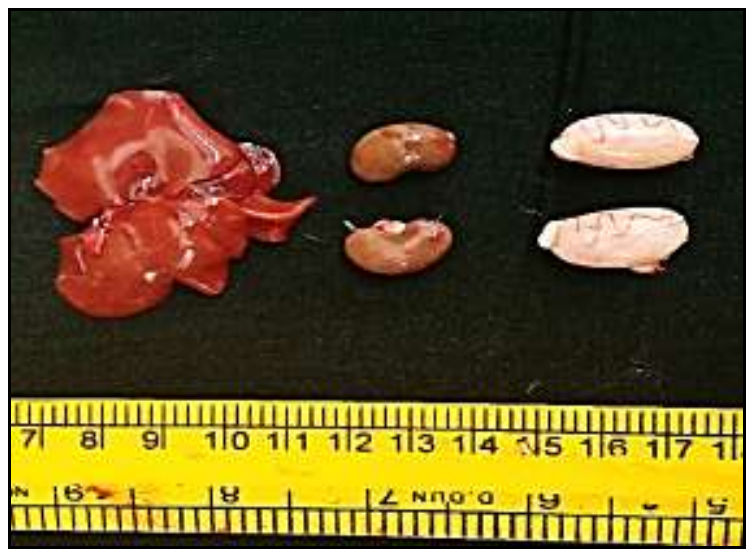


Fig.8 GLP treated rat showing severe congestion of liver, kidneys, testes and marked reduction in the size of kidneys and testicles (Group 2, Day 21)

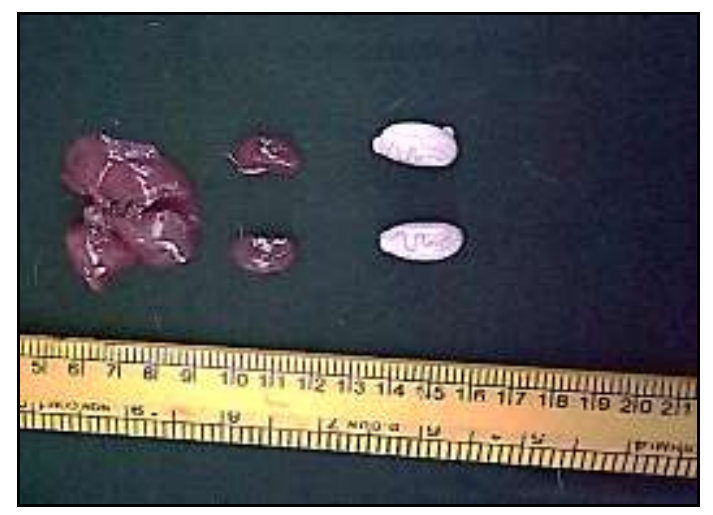

A significant $(\mathrm{P}<0.05)$ reduction in body weights were recorded in GLP treated rats(Group 2) which might be due to decreased feed and water intake on the account of toxic action of GLP on GIT and also due to oxidative stress at sub cellular level in liver and kidneys. This is in accordance with the observations of Daruich et al., (2001), Beuret et al., (2005), Jasper et al., (2012) and Tang et al., (2017). Contrary to this, statistically insignificant reduction in body weights were observed by Stout and Ruecker (1990), Cagler and Kolankaya (2008) and El-Shenawy (2009). Significantly lower mean values were noticed in group 4 rats when compared to group 1 rats, but significantly increased when compared to group 2 rats on $7^{\text {th }}$ and $21^{\text {st }}$ day of experiment, which could be due to the ameliorative action of Vitamin $\mathrm{C}$ against GLP induced cytotoxicity.

Grossly, atrophy of testicles and kidneys, severe congestion of testes, liver and kidneys, were recorded in group 2 on $7^{\text {th }}$ and $21^{\text {st }}$ day of experiment as a result of GLP intoxication on respective organs. The congestion might be due to vascular changes. Atrophy of kidneys and testicles may be due to metabolic
Fig.10 GLP+Vit. $C$ treated rat showing mild congestion of liver, kidneys and moderate reduction in the size of kidneys and testicles (Group 4, Day 21)

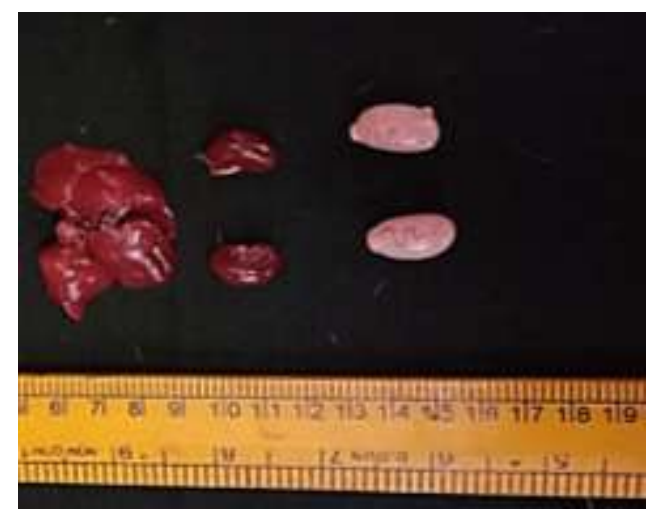

disturbance. Hypothetically, these changes are the end result of cell injury which might have involved eventual changes in bio-molecules resulted in apoptosis of injured cells. Contrary to this, Cuthbert and Jackson (1989) and McDonald and Anderson (1989) reported no gross changes on necropsy examination.

The GLP (500 mg/kg b.wt) causes significant reduction in body weights and marked alterations in organ morphometry by free radical induced damage and Vitamin $\mathrm{C}$ is a potent antioxidant capable of ameliorating the toxic effects of GLP to certain extent.

\section{Acknowledgement}

We thankfully recognize the accessibility of the necessary facilities provided by PV Narsimharao Telangana Veterinary University for smooth conduct of the clinical research.

\section{References}

Bababunmi, E. A., Olorunsogo, O. O and Bassir, O. (1979). The uncoupling effect of $\mathrm{N}$-(phosphonomethyl) glycine on isolated rat liver mitochondria. 
Biochemical Pharmacology, 28 (6): 925-927.

Beuret, C. J., Zirulnik, F and Gimenez, M. S. (2005). Effect of the herbicide glyphosate on liver lipoperoxidation in pregnant rats and their fetuses. Reproductive Toxicology, 19 (4): 501-504.

Caglar, S and Kolankaya, D. (2008). The effect of subacute and sub chronic exposure of rats to the glyphosate based herbicide Roundup. Environmental Toxicology and Pharmacology, 25 (1): 57-62

Cuthbert, J. A and Jackson, D. (1989). Glyphosate technical: acute oral toxicity (limit) test in rats. Unpublished report, (5883).

Daruich, J., Zirulnik, F and Gimenez, M. S. (2001). Effect of the herbicide glyphosate on enzymatic activity in pregnant rats and their fetuses. Environmental Research, 85 (3): 226-231.

El-Shenawy, N. S. (2009). Oxidative stress responses of rats exposed to Roundup and its active ingredient glyphosate. Environmental Toxicology and Pharmacology, 28 (3): 379-385

Feinstein, R. E. (2000). In: Post mortem procedures in Hand book of Laboratory Animal Science, Svendson, P. and Hau, J, (1): 383-396

Ikpeme, E. V., Udensi, O., Ekaluo, U. B and Solomon, T. O. (2012). Efficacy of ascorbic acid in reducing glyphosate induced toxicity in rats. British Biotechnology Journal, 2 (3): 157-168.

James, C. (2014). Global Status of Commercialized Biotech/GM Crops: 2014. International service for the acquisition of agribiotech applications (ISAAA) Brief 49.

Jasper, R., Locatelli, G. O., Pilati, C and Locatelli, C. (2012). Evaluation of biochemical, hematological and oxidative parameters in mice exposed to the herbicide glyphosateRoundup ${ }^{\circledR}$ Interdisciplinary Toxicology, 5 (3): 133-140.

Madsen, H. L., Christensen, H. H and Gottlieb-Petersen, C. (1978). Stability Constants of Copper (II), Zinc, Manganese, Calcium and Magnesium Complexes of $\mathrm{N}$-(Phosphonomethyl) glycine (Glyphosate). Acta Chemica Scandinavica. A, 32(1): 79-83.

McDonald, P and Anderson, B. T. (1989). Glyphosate technical: acute inhalation toxicity study in rats (limit test). Unpublished report, (5993).

McKenna, K and Thompson, C. (1998). Osmoregulation in clinical disorders of thirst appreciation. Clinical endocrinology, 49(2): 139-152.

Olorunsogo, O. O. (1982). Inhibition of energy dependent transhydrogenase reaction by $\mathrm{N}$-(phosphonomethyl) glycine in isolated rat liver mitochondria. Toxicology Letters, 10 (1): 91-95.

Olorunsogo, O. O., Bababunmi, E. A and Bassir, O. (1979). Effect of glyphosate on rat liver mitochondria in vivo. Bulletin of Environmental Contamination and Toxicology, 22 (1): 357-364.

Shehata, A. A., Schrodl, W., Aldin, A. A., Hafez, H. M and Kruger, M. (2013). The effect of glyphosate on potential pathogens and beneficial members of poultry microbiota in vitro. Current Microbiology, 66 (4): 350-358.

Snedecor, G. W and Cochran, G. (1994). Statistical methods, $8^{\text {th }}$ ed, IOWA State University Press, Amer, IOWA, USA.

Stout, L. D and Ruecker, F. A. (1990). Chronic study of glyphosate administered in feed to albino rats. Unpublished Study, Project No. MSL10495. Monsanto Environmental Health Laboratory, St.Louis, MO 
Tang, J., Hu, P., Li, Y., Win-Shwe, T. T and $\mathrm{Li}$, C. (2017). Ion imbalance is involved in the mechanisms of liver oxidative damage in rats exposed to glyphosate. Frontiers in Physiology, 8: 1083.

Temple, W. A and Smith, N. A. (1992). Glyphosate herbicide poisoning experience in New Zealand. The New Zealand Medical Journal, 105 (933): 173.

Tizhe, E. V., Ibrahim, N. D. G., Fatihu, M. Y., Igbokwe, I. O., George, B. D. J., Ambali, S. F and Shallangwaa, J. M.
(2013). Haematological changes induced by sub chronic glyphosate exposure: ameliorative effect of zinc in Wistar rats. Sokoto Journal of Veterinary Sciences, 11 (2): 28-35.

Youness, E. R., Agha, F. E., El-Toukhy, S. E., El-Naggar, S. M., Selim, A. A and Ibrahim, A. M. (2016). The protective effect of orange juice on glyphosate toxicity in adult male mice. Journal of Chemical and Pharmaceutical Research, 8 (3): 13-28.

\section{How to cite this article:}

Lakshmi Namratha, M., M. Lakshman, M. Jeevanalatha and Anil Kumar, B. 2019. Effect of Glyphosate (GLP) Induced Toxicity on Body Weights and Gross Pathology: Ameliorative Effect of Ascorbic Acid (AA) in Wistar Rats. Int.J.Curr.Microbiol.App.Sci. 8(10): 1486-1493. doi: https://doi.org/10.20546/ijcmas.2019.810.174 